\title{
Traumatic Cervical Artery Dissection and Ischemic Stroke: Anticoagulation or Antiplatelet Therapy? The Controversies Remain
}

\section{Dissecção traumática da artéria cervical e AVC isquêmico: anticoagulação ou terapia antiplaquetária? A polêmica continua}

\author{
Leonardo Christiaan Welling ${ }^{1}$ Camila Mariana Fukuda ${ }^{2}$ Edek Francisco de Mattos da Luz $^{2}$ \\ Mariana Schumacher Welling ${ }^{2}$ Eberval Gadelha Figueiredo ${ }^{3}$
}

1 Neurosurgeon; Professor at Universidade Estadual de Ponta Grossa, Ponta Grossa, PR, Brazil

2 Medical School Students at Universidade Estadual de Ponta Grossa,

Ponta Grossa, PR, Brazil

3 Neurosurgeon; Professor at Universidade de São Paulo, São Paulo, SP, Brazil

Arq Bras Neurocir 2015;34:331-334.

\begin{abstract}
Keywords

- ischemia

- carotid artery

- dissection

\section{Resumo}

Palavras-chave

- isquemia

- carótida interna

- dissecação

Arterial dissection of the wall of the carotid artery is a recognized and significant cause of stroke. We described a 22-year-old man presented to the emergency department after a motorcycle accident. He had a right acetabular fracture and had not complained of other symptoms. A few minutes after being admitted, the patient developed left side hemiparesis. Emergency brain magnetic resonance imaging (MRI) revealed an acute ischemia in the left basal ganglia. Conventional angiography confirmed almost complete occlusion of carotid artery lumen. We treated the patient with antiplatelet therapy and he is currently followed at the outpatient clinic with good recovery of motor symptoms. Early identification and management of cervical artery dissection is important, as it is one of the major causes of ischemic stroke in young adults. Despite previous published articles, the best treatment of carotid artery dissection, especially after trauma, remains controversial.

Dissecação da parede da artéria carótida interna é uma causa reconhecida de acidente vascular cerebral. Descrevemos um jovem de 22 anos admitido na emergência após acidente motociclístico. Inicialmente foi diagnosticado somente fratura acetabular, sem nenhuma outra queixa pelo paciente. Poucos minutos após admissão, o paciente evoluiu com hemiparesia esquerda. Encaminhado a ressonância magnética do encéfalo em caráter de urgência, identificou-se isquemia aguda nos gânglios da base à esquerda. Angiografia convencional demonstrou oclusão quase completa da artéria carótida interna. O caso foi tratado com terapia antiagregante plaquetária e atualmente o
\end{abstract}

Address for correspondence Leonardo Christiaan Welling, MD, Rua Tiradentes, 976, Centro, Ponta Grossa, PR, Brazil CEP: 84010-190 (e-mail: leonardowelling@yahoo.com.br). received

November 10, 2013

accepted

August 7, 2015

published online

October 13, 2015
DOI http://dx.doi.org/

10.1055/s-0035-1564582. ISSN 0103-5355.
Copyright $@ 2015$ by Thieme Publicações License terms

Ltda, Rio de Janeiro, Brazil.
(요 (1) $\odot$ 
paciente está em acompanhamento ambulatorial com boa recuperação dos sintomas motores. Como uma das maiores causas de acidente vascular cerebral isquêmico em jovens, a identificação precoce e manejo da dissecação cervical é importante. A depeito dos trabalhos previamente publicados, o melhor tratamento para a dissecação carótidea, especialmente após trauma, permanece controversa.

\section{Introduction}

Arterial dissection of the wall of the carotid artery causing narrowing or occlusion of the arterial lumen or acting as a source of emboli is a recognized and significant cause of cerebral ischemia and stroke. ${ }^{1}$ Dissections may be precipitated by neck or head movement and neck manipulation, including bouts of violent coughing, sneezing, or sudden deceleration. ${ }^{2}$ Alternatively, they may result from significant trauma, including non-penetrating injury to the head and neck as well as direct arterial injury. ${ }^{2}$ Although the clinical presentation of traumatic cervical artery dissection (TCAD) can sometimes appear benign in cases of isolated pain or Horner's syndrome, dissections are a major cause of ischemic stroke in young and middle-aged adults. Therefore, early recognition and appropriate management of this disorder are of great importance. ${ }^{3}$

\section{Case Report}

A 22-year-old man presented to the emergency department after a motorcycle accident. The patient had a right acetabular fracture and no complaints of any other symptoms. A few minutes after being admitted, he developed left side hemiparesis. Emergency magnetic resonance imaging (MRI) and magnetic resonance angiography (MRA) of neck and brain revealed an acute ischemia in the left basal ganglia (-Fig. 1). The wall hematoma resulted in almost complete occlusion of the arterial lumen, as observed in conventional angiography (-Fig. 2). He received treatment with antiplatelet therapy and is currently undergoing follow-up in the outpatient clinic with good recovery of motor symptoms.
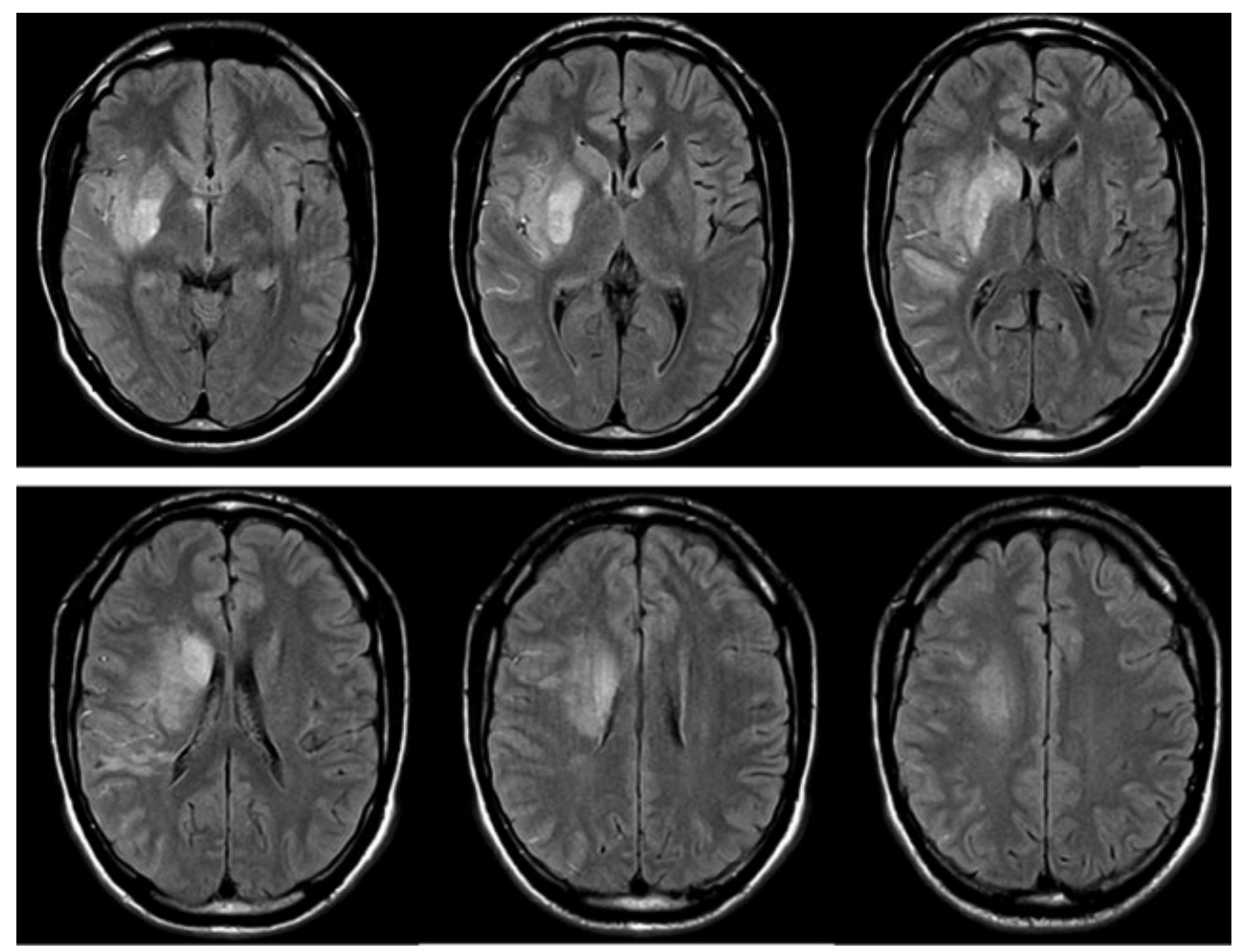

Fig. 1 Brain Magnetic resonance imaging (MRI) revealed an acute ischemia in left basal ganglia. 


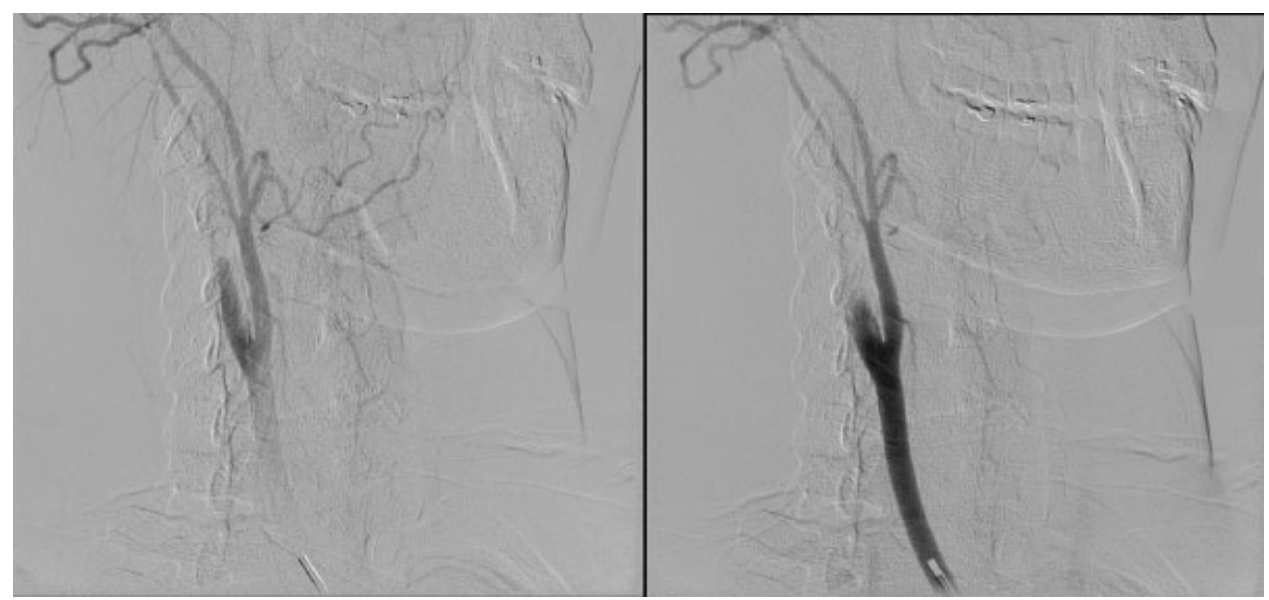

Fig. 2 Conventional angiography shows complete occlusion of the arterial lumen.

\section{Discussion}

The clinical presentation of cerebral ischemia caused by TCAD does not differ from that of cerebral ischemia attributable to other factors. Nonetheless, the pathophysiology of cervical artery dissection (CAD) remains poorly understood. Some researchers have postulated that patients with CAD could have a constitutional, at least in part, genetically determined weakness of the vessel wall and that environmental factors, such as acute infection or minor trauma, act as triggers. ${ }^{4}$

Traumas are important predisposing factors for CAD. Traumatic cervical artery dissection can occur as a result of major penetrating or non-penetrating traumas. ${ }^{5}$ In published works, CAD has been shown to occur in $\sim 1-2 \%$ of patients who have had blunt trauma, and the risk is also increased with trauma-associated injuries such as severe facial fractures and skull-base fractures. ${ }^{1-5}$

Medical treatment and prevention strategies currently rely solely on empirical data. Patients with cervical artery dissection should be treated with antiplatelets or anticoagulants to prevent future cerebrovascular ischemic events. The risk of early recurrence of stroke has led many clinicians to advocate the use of anticoagulation from presentation until 3 or 6 months after dissection. However, others believe that antiplatelet drugs might be sufficient. ${ }^{6}$ Anticoagulants might prevent embolism from a fresh thrombus; however, they are also more hazardous than antiplatelet drugs and may result in extension of the intramural hemorrhage, which occurs in a third of patients, according to MRI. ${ }^{7}$

A Cochrane review found no completed randomized trials comparing antiplatelet agents to anticoagulants. In

\section{Blunt trauma to the neck (one or more of)}

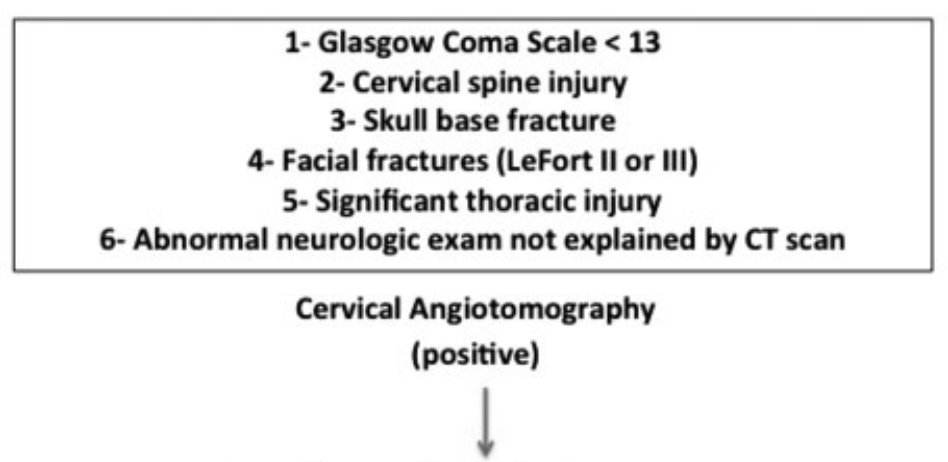

\section{Consider antithrombotic treatment}

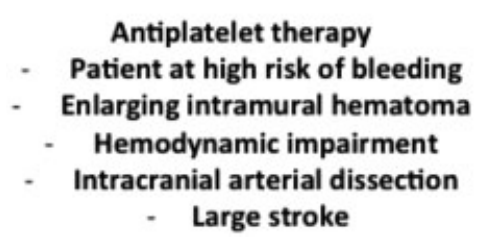

Antiplatelet therapy

- Patient at high risk of bleeding

Enlarging intramural hematoma

Hemodynamic impairment

- Large stroke

\author{
Anticoagulation \\ - Progression on antiplatelet therapy \\ - Dissected artery occlusion \\ - Free floating thrombus \\ - Evidence of cerebral embolism
}

Fig. 3 Proposed diagnostic algorithm in trauma patients. 
the 36 observational studies reviewed, there were no differences in the odds of death or recurrence of ischemic stroke, although there was a non-significant trend in favor of anticoagulants for the death or disability outcome (odds ratio, 1.77; 95\% confidence interval, 0.98-3.22). There was a $0.8 \%$ risk of symptomatic intracranial hemorrhage and $1.6 \%$ risk of major extracranial hemorrhage only in the anticoagulant group. ${ }^{8}$ In an effort to solve this question, the Cervical Artery Dissection In Stroke Study (CADISS) was established to compare the effectiveness of antiplatelet drugs with anticoagulant drugs for the prevention of recurrent stroke in patients with carotid and vertebral dissection. The results of this study shows that a recurrent stroke at 3 months is rare, with no significant difference between the two treatments. Although more strokes occurred in the antiplatelet group than in the anticoagulant group, this difference was counterbalanced by one major subarachnoid hemorrhage in the anticoagulant group. ${ }^{9}$ It is important to emphasize that the risk of recurrent events in this trial was lower than that reported in some observational studies. ${ }^{9,10}$

All the previous studies include spontaneous and traumatic causes of carotid dissections. Schneidereit et al. proposed a diagnostic algorithm and a choice of antithrombotic therapy that can be useful in trauma patients ${ }^{11}$ (-Fig. 3).

\section{Conclusion}

Early identification and management of cervical artery dissection is important, as it is one of the major causes of ischemic stroke in young adults. Aside from trauma, several environmental and genetic risk factors have been suggested to underlie TCADs, but current evidence is limited to small series. Despite the recently published trial, the CADISS, the best treatment of carotid artery dissection, especially after trauma, remains controversial.

\section{References}

1 Rubinstein SM, Peerdeman SM, van Tulder MW, Riphagen I, Haldeman S. A systematic review of the risk factors for cervical artery dissection. Stroke 2005;36(7):1575-1580

2 Redekop GJ. Extracranial carotid and vertebral artery dissection: a review. Can J Neurol Sci 2008;35(2):146-152

3 Dziewas R, Konrad C, Dräger B, et al. Cervical artery dissectionclinical features, risk factors, therapy and outcome in 126 patients. J Neurol 2003;250(10):1179-1184

4 Lee VH, Brown RD Jr, Mandrekar JN, Mokri B. Incidence and outcome of cervical artery dissection: a population-based study. Neurology 2006;67(10):1809-1812

5 Kim YK, Schulman S. Cervical artery dissection: pathology, epidemiology and management. Thromb Res 2009;123(6): 810-821

6 Arauz A, Hoyos L, Espinoza C, Cantú C, Barinagarrementeria F, Román G. Dissection of cervical arteries: Long-term follow-up study of 130 consecutive cases. Cerebrovasc Dis 2006;22(2-3): 150-154

7 Beletsky V, Nadareishvili Z, Lynch J, Shuaib A, Woolfenden A, Norris JW; Canadian Stroke Consortium. Cervical arterial dissection: time for a therapeutic trial? Stroke 2003;34(12): 2856-2860

8 Lyrer P, Engelter S. Antithrombotic drugs for carotid artery dissection. Cochrane Database Syst Rev 2003;(3):CD000255

9 Markus HS, Hayter E, Levi C, Feldman A, Venables G, Norris J; CADISS trial investigators. Antiplatelet treatment compared with anticoagulation treatment for cervical artery dissection (CADISS): a randomised trial. Lancet Neurol 2015;14(4):361-367

10 Georgiadis D, Arnold M, von Buedingen HC, et al. Aspirin vs anticoagulation in carotid artery dissection: a study of 298 patients. Neurology 2009;72(21):1810-1815

11 Schneidereit NP, Simons R, Nicolaou S, et al. Utility of screening for blunt vascular neck injuries with computed tomographic angiography. J Trauma 2006;60:209-215, discussion 215-216 